Vol 1. No. 4, Oktober 2021 P-ISSN : 2774-8014, e-ISSN : 2774-7034

\title{
PROBLEM BASED LEARNING SOLUSI PEMBELAJARAN DALAM MATA PELAJARAN MATEMATIKA DENGAN TOPIK KPK \& FPB DI KELAS IV SDI RAMAH ANAK CILODONG DEPOK
}

\author{
IIN QURAISIN \\ Pascasarjana PMIPA, Universitas Indraprasta PGRI, Jakarta \\ e-mail: iin.quraisin@gmail.com
}

\begin{abstract}
ABSTRAK
Pembelajaran matematika pada topik KPK dan FPB merupakan salah satu materi yang dianggap "sulit" oleh siswa. Karena materi ini siswa dituntut harus sudah mampu memahami perkalian dan pembagian dengan sangat baik. Jika pemahaman seorang siswa sudah mahir di perkalian dan pembagiannya, maka secara otomatis akan sangat mudah bagi mereka untuk menyelesaikan soal-soal yang berkaitan dengan KPK dan FPB. Dan biasanya guru untuk menyampaikan materi ini lebih sering/pada umumnya menggunakan model pembelajaran klasik atau ceramah. Karena model pembelajaran ini dianggap paling "jitu" dalam memberikan pemahaman kepada siswa. Namun kenyataannya, siswa menjadi semakin kurang tertarik dan menambahkan label "sulit sekali" terhadap pembelajaran matematika. Dari sinilah, penelitian dilakukan dengan memberikan model pembelajaran yang berbeda, yaitu menggunakan model pembelajaran PBL (Problem Based Learning) atau disebut juga dengan PBM (Pembelajaran Berbasis Masalah). Dasar model pembelajaran ini yaitu siswa diajak untuk menemukan solusi dalam menyelesaikan soal cerita yang berkaitan dengan soal-soal KPK dan FPB dalam diskusi kelompoknya masing-masing, agar siswa tertarik dan tertantang dalam menyelesaikan soal tersebut. Penelitian ini dilakukan melalui penelitian tindakan kelas (PTK) dengan 3 tahapan/siklus (Pra-Siklus, Siklus I, dan Siklus II) didalamnya. Model Pembelajaran Berbasis Masalah digunakan pada siklus I dan II. Berdasarkan hasil penelitian yang didapatkan pada prasiklus dan siklus I, yaitu terjadi peningkatan hasil belajar siswa dari hanya terdapat $33 \%$ siswa yang mendapat nilai di atas KKM menjadi 52\% siswa yang tuntas KKM. Setelah dilakukan perbaikan pembelajaran pada siklus I menuju siklus II, terjadi peningkatan kembali pada nilai perolehan siswa yaitu dari 52\% siswa tuntas KKM menjadi 95\% siswa tuntas KKM. Dari hasil penelitian ini, dapat disimpulkan bahwa hasil belajar matematika yang diberi model Pembelajaran Berbasis Masalah atau PBL (Problem Based Learning) lebih baik daripada hasil belajar matematika siswa tanpa menggunakan model Pembelajaran Berbasis Masalah.
\end{abstract}

Kata Kunci: Pembelajaran Matematika, Model PBM/PBL, KPK dan FPB

\section{ABSTRACT}

Learning mathematics on the topic of KPK and FPB is one of the materials considered "difficult" by students. Because of this material, students are required to be able to understand multiplication and division very well. If a student's understanding is proficient in multiplication and division, it will automatically be very easy for them to solve questions related to the KPK and FPB. And usually the teacher to deliver this material more often/generally uses classical learning models or lectures. Because this learning model is considered to be the most "correct" in providing understanding to students. But in reality, students are becoming less and less interested and add the label "very difficult" to learning mathematics. From here, the research was conducted by providing a different learning model, namely using the PBL (Problem Based Learning) learning model or also known as PBM (Problem Based Learning). The basis of this learning model is that students are invited to find solutions in solving story problems related to KPK and FPB questions in their respective group discussions, so that students are interested and challenged in solving these problems. This research was conducted through classroom action research (CAR) with 3 stages/cycles (Pre-Cycle, Cycle I, and Cycle II) in it. ProblemBased Learning Model is used in cycles I and II. Based on the research results obtained in the pre-cycle and cycle I, there was an increase in student learning outcomes from only $33 \%$ of 


\section{ELEMENTARY : Jurnal Inovasi Pendidikan Dasar \\ Vol 1. No. 4, Oktober 2021 P-ISSN : 2774-8014, e-ISSN : 2774-7034}

students who scored above the KKM to $52 \%$ of students who completed the KKM. After improving learning in cycle I to cycle II, there was an increase again in student acquisition scores, from $52 \%$ of students who completed the KKM to $95 \%$ of students who completed the KKM. From the results of this study, it can be concluded that the mathematics learning outcomes given the Problem Based Learning model or PBL (Problem Based Learning) are better than the students' mathematics learning outcomes without using the Problem Based Learning model.

Keywords: Mathematics Learning, PBM/PBL Model, KPK and FPB

\section{PENDAHULUAN}

Pendidikan matematika di berbagai negara, terutama negara-negara maju telah berkembang dengan cepat, disesuaikan dengan kebutuhan dan tantangan yang bernuansa kemajuan sains dan teknologi. Matematika adalah ilmu yang mempelajari tentang besaran, struktur, bangun ruang, dan perubahan-perubahan yang pada suatu bilangan. Matematika berasal dari bahasa Yunani Mathematikos yang artinya ilmu pasti. Dan Kamus Besar Bahasa Indonesia, definisi matematika adalah ilmu tentang bilangan dan segala sesuatu yang berhubungan dengannya yang mencakup segala bentuk prosedur operasional yang digunakan dalam menyelesaikan masalah mengenai bilangan. Sebagai pengetahuan, matematika mempunyai ciri-ciri khusus antara lain; abstrak, deduktif, konsisten, hierarkis, dan logis. Soedjadi (1999) menyatakan bahwa keabstrakan matematika karena objek dasarnya abstrak, yaitu fakta, konsep, operasi, dan prinsip. Ciri keabstrakan matematika beserta ciri lainnya yang tidak sederhana, menyebabkan matematika tidak mudah untuk dipelajari, dan pada akhirnya banyak siswa yang kurang tertarik terhadap matematika, bahkan ada yang "khawatir dan takut" terhadap pelajaran ini.

Menurut Rohmayasari (2010:68) didapat bahwa sikap dan kemampuan berpikir matematika siswa masih rendah dan belum memuaskan, diantaranya: 1) Para siswa masih merasa malas untuk mempelajari matematika karena terlalu banyak rumus. 2) Para siswa menganggap bahwa pelajaran matematika adalah pelajaran yang membosankan. 3) Matematika masih sulit dipahami siswa. 4) Soal matematika yang diberikan sulit untuk dikerjakan. 5) Siswa masih merasa bingung dalam mengaplikasikan konsep matematika dalam kehidupan seharihari. 6) Soal yang diberikan adalah soal-soal rutin yang kurang meningkatkan kemampuan berpikir matematika siswa. 7) Soal yang diberikan tidak berhubungan dengan kehidupan seharihari dan siswa belum terbiasa diberikan soal-soal tidak rutin. Faktanya bahwa siswa lebih mudah mengerjakan soal-soal matematika yang hanya berupa bilangan/angka-angka saja, dan apabila diberikan soal yang berupa masalah yang harus diselesaikan dalam bentuk soal cerita mereka cenderung tidak bisa mengerjakan soal tersebut.

Satu dari sejumlah materi mata pelajaran matematika yang harus dipelajari siswa yaitu Kelipatan Persekutuan Terkecil (KPK) dan Faktor Persekutuan Terbesar (FPB). Dalam mencari KPK dan FPB, guru pada umumnya menggunakan metode pembelajaran klasikal, yaitu model ceramah. Model ini, guru akan mengajarkan metode sederhana dan metode faktorial/pohon faktor. Namun kedua metode ini seringkali siswa merasa kesulitan dalam pengerjaannya yang pada akhirnya siswa cenderung khawatir takut salah, jenuh dan bosan sehingga akan mempengaruhi nilai hasil belajar mereka. Untuk mengatasi hal tersebut, guru diharapkan mampu menerapkan suatu model pembelajaran yang dapat meningkatkan motivasi siswa dalam menyelesaikan tugas yang diberikan serta aktif dalam belajar. Hal ini sesuai dengan pendapat Asmani (2010:211) yang menyatakan bahwa guru yang baik adalah guru yang sedikit bicara banyak diamnya. Maksud dari pernyataan tersebut adalah guru hanya sebagai fasilitator saja, sedangkan peserta didik yang harus aktif melakukan berbagai aktivitas dalam proses pembelajaran dengan melakukan diskusi, kerja kelompok, debat bertanya, dan lempar gagasan. Kegiatan atau aktivitas ini akan mewujudkan pembelajaran aktif pada peserta didiknya. Dan Pembelajaran Berbasis Masalah (PBM) atau Problem Based Learning (PBL) merupakan model pembelajaran yang dapat mendorong siswa untuk aktif dalam proses pembelajarannya, karena 
mereka akan mengenal cara belajar dan bekerjasama dalam kelompok untuk penyelesaian masalah-masalah di dunia nyata khususnya yang berkaitan dengan materi KPK dan FPB. Berdasarkan latar belakang tersebut, penulis tertarik untuk melakukan penelitian menggunakan model pembelajaran berbasis masalah (PBM) dalam upaya meningkatkan hasil belajar matematika siswa.

\section{METODE PENELITIAN}

Penelitian ini merupakan penelitian tindakan kelas, dimana data yang diambil yaitu dari siswa satu kelas. Dan perbedaan yang paling dominan dalam penelitian ini dengan penelitian yang lain yaitu melibatkan rekan sejawat saat pelaksanaan penelitian tersebut. Hal ini diharapkan, rekan sejawat tersebut dapat memberikan masukan/penilaian yang objektif, kekurangan dan kelebihan yang ada terhadap pembelajaran tersebut yang dilakukan oleh guru yang melakukan penelitian tindakan kelas ini. Sehingga dari penilaian ini, guru dapat merencanakan/merancang pembelajaran yang lebih baik dengan menggunakan model pembelajaran yang lebih inovatif.

Prosedur penelitian tindakan kelas ini terdiri dari empat komponen pokok penelitian kelas, yaitu: tahap pertama adalah tahap perencanaan/planning (menetapkan jadwal penelitian, membuat rancangan pembelajaran, membentuk kelompok belajar), tahap kedua adalah tindakan/pelaksanaan, tahap ketiga adalah tahap pengamatan/observing, dan terakhir yaitu tahap keempat adalah tahap refleksi. Pada para siklus, model pembelajaran masih menggunakan metode klasikal yaitu model ceramah, dan tahap siklus I serta siklus II guru baru menggunakan model pembelajaran PBL (Problem Based Learning) sebagai langkah perbaikannya. Maka jika dibuat bagan alur tahapan penelitiannya yaitu sebagai berikut:

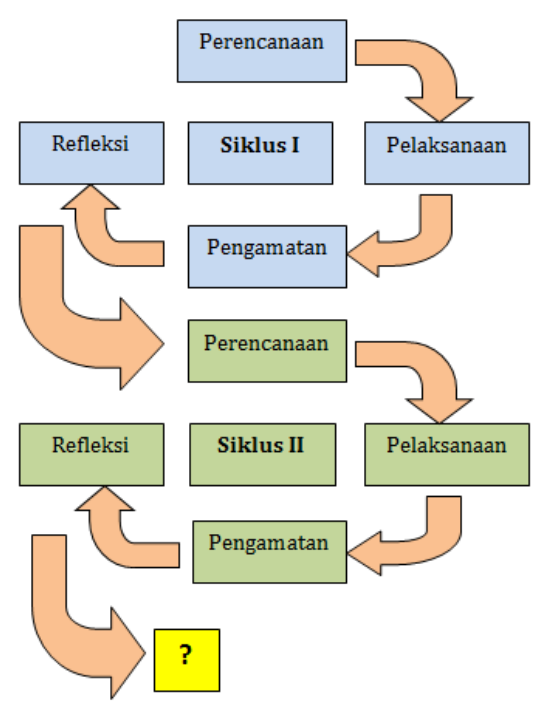

\section{Gambar 1. Skema Penelitian Tindakan Kelas}

Data yang diperoleh yaitu data kuantitatif yang diperoleh dari hasil evaluasi siswa pada saat observasi dan setiap siklusnya. Instrumen penilaian yang digunakan pada setiap siklus yaitu soal pilihan ganda, isian singkat, dan uraian yang dikerjakan secara individu. Teknik analisis data yang digunakan dalam penelitian ini adalah statistic descriptive comparative yaitu dengan membandingkan hasil evaluasi siswa pada pra siklus, siklus I dan siklus II dengan KKM Matematika kelas IV SD Islam Ramah Anak. Berdasarkan perbandingan tersebut dapat diperoleh jumlah siswa yang mendapat nilai di bawah ataupun yang sudah mencapai KKM baik di siklus I maupun siklus II. 


\section{HASIL DAN PEMBAHASAN}

\section{Hasil}

Setelah dilakukan evaluasi pada setiap siklusnya diperoleh data tentang hasil belajar matematika siswa yang sebelum dan sesudah menggunakan pembelajaran dengan model pembelajaran berbasis masalah/ $P B L$. Adapun nilai KKM yang harus dicapai siswa kelas IV pada mata pelajaran matematika adalah 70 . Tes hasil belajar pada penelitian ini diikuti oleh 21 orang siswa. Data tersebut dianalisis sehingga diperoleh deskripsi statistik nilai dari kelas tersebut, seperti terlihat pada tabel berikut:

$$
\text { nilai rata }- \text { rata }=\frac{(x 1+x 2+x 3+x 4+\ldots+x n)}{n}
$$

Tabel 1. Hasil Tes Siklus I dan Siklus II

\begin{tabular}{|c|c|c|c|}
\hline No & $\begin{array}{c}\text { Nilai } \\
\text { Matematika pra } \\
\text { siklus }\end{array}$ & $\begin{array}{c}\text { Nilai Matematika } \\
\text { siklus I }\end{array}$ & $\begin{array}{c}\text { Nilai Matematika } \\
\text { siklus II }\end{array}$ \\
\hline 1 & 50 & 60 & 68 \\
\hline 2 & 68 & 70 & 85 \\
\hline 3 & 72 & 80 & 90 \\
\hline 4 & 63 & 65 & 75 \\
\hline 5 & 68 & 70 & 85 \\
\hline 6 & 77 & 85 & 95 \\
\hline 7 & 63 & 66 & 80 \\
\hline 8 & 54 & 60 & 75 \\
\hline 9 & 60 & 65 & 84 \\
\hline 10 & 78 & 88 & 100 \\
\hline 11 & 75 & 80 & 96 \\
\hline 12 & 63 & 67 & 80 \\
\hline 13 & 67 & 70 & 82 \\
\hline 14 & 67 & 70 & 85 \\
\hline 15 & 62 & 65 & 80 \\
\hline 16 & 56 & 65 & 78 \\
\hline 17 & 70 & 80 & 95 \\
\hline 18 & 56 & 65 & 78 \\
\hline 19 & 73 & 75 & 85 \\
\hline 20 & 60 & 65 & 78 \\
\hline 21 & 72 & 85 & 100 \\
\hline Nilai rata-rata & 65 & 71 & 84 \\
\hline
\end{tabular}

Berdasarkan tabel di atas dapat diketahui bahwa nilai rata-rata hasil belajar matematika siswa pada siklus I lebih tinggi dari nilai rata-rata pada pra-siklus dan nilai rata-rata hasil belajar matematika siswa pada siklus II lebih tinggi dari nilai rata-rata pada siklus I. Berikut persentase peningkatan nilai hasil belajar siswa yang dicapai dari tahap pra-siklus, siklus I, dan sampai terakhir di siklus II. 


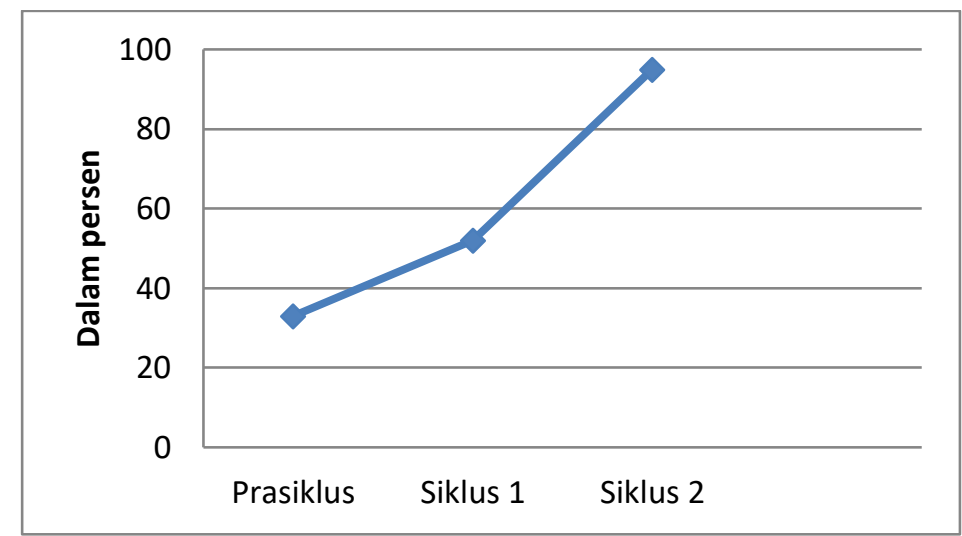

\section{Gambar 2. Diagram Grafik Peningkatan Persentase Hasil Nilai Evaluasi Siswa Per siklusnya}

\section{Pembahasan}

Dari hasil análisis data evaluasi terakhir pada siklus II diketahui bahwa hasil belajar matematika dengan topik KPK dan FPB siswa lebih baik daripada di tahap pra-siklus. Ini menunjukkan bahwa penggunaan model pembelajaran berbasis masalah $/ P B L$ dalam pembelajaran matematika dengan topik KPK dan FPB memiliki dampak positif terhadap hasil belajar matematika siswa. Hal ini terlihat dari nilai tertinggi pada pra siklus yaitu 90 dan nilai terendahnya 38; dan pada siklus I nilai tertingginya yaitu 95 dan nilai terendahnya 60; serta pada siklus II nilai tertingginya yaitu 100 dan nilai terendahnya 68. Peningkatan nilai hasil belajar matematika siswa pada tahap siklus I dan II daripada tahap pra siklus disebabkan karena pada saat pembelajaran dengan menggunakan model pembelajaran berbasis masalah/ $P B L$ siswa lebih banyak menghadapi masalah/latihan-latihan berupa soal cerita yang berkaitan dengan KPK dan FPB yang diterapkan kesemppada kondisi sebenarnya dengan mendiskusikannya lalu memecahkan masalah tersebut bersama dengan teman sekelompoknya. Sehingga memberikan kesempatan yang luas bagi siswa untuk memahami materi matematika pada topik KPK dan FPB serta menjadi terlatih dalam mengerjakan soal-soal matematika tersebut. Kondisi pembelajaran yang kondusif ini juga didukung oleh usaha guru yang selalu memeriksa, menilai, dan mengembalikan hasil kerja siswa yang dapat memacu semangat dan gairah siswa untuk memperoleh hasil yang lebih baik lagi. Berbeda pada saat pra siklus, siswa juga diberi latihan kemudian dinilai dan dikembalikan lagi ke siswa namun setelah siswa melihat hasil kerjanya, mereka tidak berusaha untuk memperbaiki kesalahan mereka dalam mengerjakan latihan. Siswa malas untuk bertanya kembali pada guru atau pada temannya yang lebih paham. Sehingga kesalahan mereka dalam memahami konsep KPK dan FPB pada matematika terulang lagi saat mengerjakan soal-soal latihan berikutnya. Hal ini sesuai dengan yang dijelaskan oleh Anitah (2019: 5.32) bahwa model pembelajaran berbasis masalah memiliki beberapa keunggulan yaitu antara lain: mengembangkan kemampuan berpikir ilmiah, mengembangkan kemampuan berpikir kritis, mempelajari bahan pelajaran yang actual dengan kebutuhan dan perkembangan masyarakat, jika dilaksanakan secara berkelompok dapat mengembangkan kemampuan sosial siswa, dan dapat mengoptimalkan kemampuan siswa. Hasil penelitian ini sejalan dengan peneliti lain yang dilakukan oleh Hidayatun Nisa pada tahun 2016 yang juga menggunakan model pembelajaran berbasis masalah $/ P B L$ dalam penelitiannya yang berjudul "Pengaruh Pembelajaran Berbasis Masalah Terhadap Hasil Belajar Siswa dan sikap Siswa pada Mata Pelajaran Kimia" menyimpulkan bahwa hasil belajar siswa dan sikap siswa yang diajar menggunakan metode Pembelajaran Berbasis Masalah (PBM) lebih tinggi dan lebih aktif dari hasil belajar dan sikap siswa pada materi ikatan kimia yang diajar dengan metode klasikal. Dengan kata lain, dapat disimpulkan terdapat pengaruh positif dari penerapan pembelajaran berbasis masalah terhadap hasil belajar kognitif dan sikap siswa pada pembelajaran kimia. Dan hasil penelitian ini juga sejalan dengan peneliti lainnya lagi yaitu yang dilakukan oleh Rini Setiyowati pada tahun 2016 yang menggunakan model pembelajaran berbasis masalah dalam 
penelitiannya yang berjudul "Pengaruh Model Pembelajaran Berbasis Masalah Terhadap Hasil Belajar Di SMAN 1 Pacet”. Dimana beliau menyimpulkan bahwa: (1) terdapat pengaruh model pembelajaran berbasis masalah terhadap motivasi belajar peserta didik dalam pembelajaran PPKn dengan hasil signifikasi sebesar 10,933 lebih besar dari 3,09; (2) terdapat pengaruh model pembelajaran berbasis masalah terhadap hasil belajar peserta didik dalam pembelajaran PPKn dengan hasil signifikasi sebesar 32,737 lebih besar dari 3,09. Berdasarkan uraian diatas serta dukungan dari hasil penelitian terdahulu dapat disimpulkan bahwa pembelajaran dengan menggunakan model pembelajaran berbasis masalah jauh lebih baik daripada metode klasikal/konvensional.

\section{KESIMPULAN}

Memberikan arahan tugas diawal sebelum pembelajaran dimulai, berupa permasalahan matematika berkaitan dengan materi KPK dan FPB kepada siswa dan sebagai bahan diskusi kelompok dapat meningkatkan respon belajar siswa pada saat pembelajaran berlangsung. Selain itu dapat memberikan kesempatan luas bagi siswa untuk mengembangkan pengetahuan kognitif dan sosialnya sehingga hasil belajar siswa lebih baik lagi. Pemberian tugas awal yang dirancang dalam bentuk lembar diskusi yang diteruskan dengan pemberian latihan secara mandiri kepada siswa secara berkelanjutan setiap selesai materi dibicarakan dapat menambah pemahaman yang lebih baik bagi siswa, ini terbukti dari nilai rata-rata pada tahap siklus I dan II lebih tinggi daripada nilai rata-rata siswa pada tahap pra siklus. Dengan penggunaan model pembelajaran berbasis masalah ini diharapkan peserta didik mempunyai kesempatan untuk memperkaya dan memperluas pengetahuan serta pengalamannya.

\section{DAFTAR PUSTAKA}

Anitah W, Sri, DKK (2019). Strategi Pembelajaran di SD. Tangerang Selatan: Penerbit Universitas Terbuka.

HELFI, D. . (2021). Penggunaan Metode Resitasi Dalam Pembelajaran Matematika Di Kelas VIII SMP Pembangunan UNP Padang Tahun Pelajaran 2005/2006 . SECONDARY: Jurnal Inovasi Pendidikan Menengah , 1(4), 323-328. https://doi.org/10.51878/secondary.v1i4.628

Muhsetyo, Gatot, DKK (2019). Pembelajaran Matematika SD. Tangerang Selatan: Universitas Terbuka.

Mulyani, Sumantri (2019). Perkembangan Peserta Didik. Tangerang Selatan: Universitas Terbuka.

Nisa, Hidayatun (2016). Pengaruh Pembelajaran Berbasis Masalah Terhadap Hasil Belajar Siswa dan Sikap Siswa Pada Mata Pelajaran Kimia. Skripsi Sarjana, Universitas Negeri Semarang. Retrieved from http://lib.unnes.ac.id/26777/1/4301411019.pdf.

Setiyowati, R., Kurniawan, M. W., \& Widodo, R. (2020). Pengaruh Model Pembelajaran Berbasis Masalah Terhadap Hasil Belajar Di SMAN 1 Pacet. Jurnal Civic Hukum, 5(1), 86-96. https://doi.org/10.22219/jch.v5i1.11151

Shoimin, Aris (2014). 68 Model Pembelajaran Inovatif dalam Kurikulum 2013. Yogyakarta: Ar-Ruzz Media.

Wardani, IG.A.K. (2008). Penelitian Tindakan Kelas. Jakarta: Universitas Terbuka.

Wardani, IG.A.K., Julaeha, S., \& Marsinah, N. (2005). Buku Materi Pokok: Pemantapan Kemampuan Profesional (Panduan). Jakarta: Universitas Terbuka. 